\title{
Characterization and functional properties of the $\alpha$-amylase inhibitor ( $\alpha$-AI) from kidney bean (Phaseolus vulgaris) seeds
}

\author{
Véronique Le Berre-Anton a , Coralie Bompard-Gilles ${ }^{\mathrm{b}}$, Françoise Payan ${ }^{\mathrm{b}}$, Pierre Rougé ${ }^{\mathrm{a}, *}$ \\ ${ }^{a}$ Institut de Pharmacologie et Biologie Structurale, UPS-CNRS No. 9062, 205 Route de Narbonne, 31077 Toulouse Cedex, France \\ b AFMB-IBSM-CNRS, 31 Chemin Joseph Aiguier, 13402 Marseille Cedex 20, France
}

Received 26 March 1997; accepted 12 June 1997

\begin{abstract}
Alpha-amylase inhibitor ( $\alpha$-AI) from kidney bean (Phaseolus vulgaris L. cv Tendergreen) seeds has been purified to homogeneity by heat treatment in acidic medium, ammonium sulphate fractionation, chromatofocusing and gel filtration. Two isoforms, $\alpha$-AI1 and $\alpha$-AI1', of $43 \mathrm{kDa}$ have been isolated which differ from each other by their isoelectric points and neutral sugar contents. The major isoform $\alpha$-AI1 inhibited human and porcine pancreatic $\alpha$-amylases (PPA) but was devoid of activity on $\alpha$-amylases of bacterial or fungal origins. As shown on the Lineweaver-Burk plots, the nature of the inhibition is explained by a mixed non-competitive inhibition mechanism. $\alpha$-AI1 formed a 1:2 stoichiometric complex with PPA which showed an optimum $\mathrm{pH}$ of 4.5 at $30^{\circ} \mathrm{C}$. Owing to the low optimum $\mathrm{pH}$ found for $\alpha$-AI activity, inhibitor-containing diets such as beans or transgenic plants expressing $\alpha$-AI should be devoid of any harmful effect on human health. (C) 1997 Elsevier Science B.V.
\end{abstract}

Keywords: $\alpha$-Amylase inhibitor; Porcine pancreatic $\alpha$-amylase; (Phaseolus vulgaris)

\section{Introduction}

Proteinaceous inhibitors of the important digestive enzyme $\alpha$-amylase [1,4- $\alpha$-D-glucan glucanohydrolase, EC 3.2.1.1] are widespread in plants, notably in cereals (wheat, barley) and legume (beans). In con-

Abbreviations: $\alpha-A I$ : $\alpha$-Amylase inhibitor; $\alpha$-AI1: Isoform 1 of $\alpha$-amylase inhibitor; $\alpha$-AI1': Isoform 2 of $\alpha$-amylase inhibitor; PPA: Porcine pancreatic $\alpha$-amylase; DNS: Dinitrosalicylic acid reagent; PHA-E: Erythroagglutinating subunit of Phaseolus vulgaris lectin; PHA-L: Leucoagglutinating subunit of Phaseolus vulgaris lectin; SPR: Surface plasmon resonance; buffer 1: 100 $\mathrm{mM}$ Tris, $150 \mathrm{mM} \mathrm{NaCl}$ buffer ( $\mathrm{pH}$ 7.6)

* Corresponding author: IPBS-CNRS, Faculté des Sciences Pharmaceutiques, Chemin des Maraîchers, Toulouse Cedex, France. Fax: + 32-561551672; E-mail: rouge@email.cict.fr trast to cereals $\alpha$-amylase inhibitors, which have been extensively studied [1,2], little is known on the structural features and properties of legume $\alpha$ amylase inhibitors [5-8]. However, more attention is now being payed to these legume proteins for two main reasons. First, they widely occur in both human and cattle diets and could therefore diminish the digestibility of starch and starch-derived products by inhibiting the $\alpha$-amylase enzymes. The use, in the early 1980s, of crude extracts of kidney bean as starch blockers to control human non-insulin-dependant diabetes mellitus and obesity, was hampered by their very low inhibitor content [9] and the presence of potentially harmful lectins (PHA) and trypsin inhibitors [10]. Nevertheless, further investigations on humans showed that purified $\alpha$-AI perfused into the 
duodenum significantly inhibited intraluminal amylase activity [11] while ingested with dietary starch, it significantly reduced the postprandial increase in glucose of both normal and diabetic patients [12]. Second, their use as insecticidal proteins to prevent the attack of predatory insects to susceptible seeds [13$15]$. Because $\alpha$-AI inhibits the development of bruchid beetles, its gene is considered as potentially useful for crop protection via plant genetic engineering [16-18].

$\alpha$-AI has been purified and partially characterised from different varieties of the common bean, including the white kidney bean $[19,20]$, the red kidney bean [21-23] and the black kidney bean [24]. $\alpha$-AIs have been described as oligomeric proteins composed of glycopeptide subunits. $\alpha$-AI from the white kidney bean was found to be composed of non-covalently bound $\alpha(10.8 \mathrm{kDa})$ and $\beta(15 \mathrm{kDa})$ glycopeptide subunits $[20,25]$. Optimal inhibitory activity occurred at $\mathrm{pH} 5.5$ and $37^{\circ} \mathrm{C}$, and measurement of the stoichiometry of inhibition showed that a $1: 1$ complex is formed with porcine pancreatic $\alpha$-amylase $[19,21,22]$. The inhibitor does not inhibit plant, fungal or bacterial $\alpha$-amylases, but blocks the activity of salivary and pancreatic amylases of humans and mammals and the $\alpha$-amylase of insects [21].

Although the biochemical properties of legume $\alpha$-AIs have been studied for over 20 years, some discrepancies dealing with their physico-chemical and functional properties have been frequently reported. In addition, only a little is known on their structural features, and their inhibition mechanism remains to be studied in details. In the present work, $\alpha$-AI from kidney bean (Phaseolus vulgaris L.) cv Tendergreen was isolated according to a new isolation procedure and some results on its physico-chemical and functional properties are presented to get an insight in the interaction between $\alpha$-AI and $\alpha$-amylase.

\section{Materials and methods}

\subsection{Materials and reagents}

The beans from which $\alpha$-amylase inhibitor was prepared were mature seeds of kidney bean ( $P$. vulgaris L., cv. Tendergreen), purchased from Verilhac, Annonay, France.

Sigma provided us for porcine pancreatic $\alpha$ - amylase Type I-A, Calbiochem for human pancreatic and Bacillus subtilis $\alpha$-amylases and ICN for Aspergillus oryzae $\alpha$-amylase. Soluble starch, 4-chloro1-naphthol and $\mathrm{H}_{2} \mathrm{O}_{2}$ were from Sigma. Sephadex G 200, Superdex G75, PBE 94 and ready-made 12.5, $20 \%$ acrylamide gels and IEF 3-9 gels were purchased from Pharmacia. Biotinylated Con A was from EY. Laboratories, USA and Streptavidine peroxidase from Boehringer Mannheim. Gelatin was purchased from BioRad.

Sensor chips (CM 5) and all the chemicals required for the activation of the carboxymethylated dextran and the immobilization of glycoproteins (100 $\mathrm{mM} N$-hydroxysuccinimide, $400 \mathrm{mM} N$-ethyl- $N^{\prime}-$ (3-dimethylaminopropyl) carbodiimide hydrochloride, and $1 \mathrm{M}$ ethanolamine hydrochloride adjusted to $\mathrm{pH} 8.5$ with $\mathrm{NaOH}$ ) were obtained from Pharmacia Biosensor AB.

\subsection{Purification of $\alpha$-amylase inhibitor}

The inhibitor was purified from kidney bean meal. Bean meal $(100 \mathrm{~g})$ was stirred overnight with water $\left(5.5 \mathrm{ml} \mathrm{g}^{-1}\right)$ at $4^{\circ} \mathrm{C}$. The homogenate was centrifuged at $1100 \times \mathrm{g}$ for $10 \mathrm{~min}$ at $4^{\circ} \mathrm{C}$ and the resulting supernatant was filtered through cotton wool to remove the floating particles. The supernatant was then buffered by adding $110 \mu \mathrm{lml}^{-1}$ of $200 \mathrm{mM}$ succinate buffer ( $\mathrm{pH} 3.8$ ) containing $10 \mathrm{mM} \mathrm{CaCl}_{2}$, and heated in a water bath at $70^{\circ} \mathrm{C}$ for $10 \mathrm{~min}$ to destroy the endogenous amylolytic activity. The protein precipitate was removed by centrifugation at $11400 \times \mathrm{g}$ for $10 \mathrm{~min}$ at $4^{\circ} \mathrm{C}$ and the supernatant was filtered through cotton wool and brought to $\mathrm{pH} 5.6$ with $\mathrm{NaOH}$. Protein fraction precipitated at $40 \%$ ammonium sulphate saturation was dialysed and lyophilised. The lyophilised material $(200 \mathrm{mg}$ ) was dissolved in $25 \mathrm{mM}$ L-histidine monohydrochloride buffer $\mathrm{pH} 6.2$ $(5 \mathrm{ml})$ and after centrifugation at $15000 \mathrm{~g}$ for $10 \mathrm{~min}$ at $4^{\circ} \mathrm{C}$, the supernatant was loaded onto a column (40 $\mathrm{cm} \times 1 \mathrm{~cm}, 28 \mathrm{ml}$ bed volume) of PBE 94 (Pharmacia) equilibrated with the same buffer. The column was eluted with a mixture of Polybuffer $96(3 \%$, $\mathrm{v} / \mathrm{v})$ and Polybuffer $74(5 \%, \mathrm{v} / \mathrm{v})$ adjusted to $\mathrm{pH} 4.0$ with $\mathrm{HCl}$. Two inhibitor-containing fractions eluted around $\mathrm{pH} 4.6(\alpha-\mathrm{AI}$ isoform 1: $\alpha$-AI1) and 4.3 $\left(\alpha-\mathrm{AI}\right.$ isoform 2: $\alpha$-AI1 $\left.{ }^{\prime}\right)$ were pooled and precipitated at $90 \%$ ammonium sulphate saturation. The 
resulting protein precipitate was dialysed and lyophilised. The ultimate purification procedure was performed by chromatography on Sephadex G 200. The lyophilised $\alpha$-AI isoform 1 or $\alpha$-AI isoform 2 containing materials, dissolved in $0.5 \mathrm{ml}$ of $100 \mathrm{mM}$ Tris, $150 \mathrm{mM} \mathrm{NaCl}$ buffer ( $\mathrm{pH} 7.6)$ (buffer 1) was loaded onto the Sephadex G 200 column $(100 \mathrm{~cm} \times$ $1.5 \mathrm{~cm}, 177 \mathrm{ml}$ bed volume) equilibrated with the same buffer. The elution was performed at a flow rate of $8.7 \mathrm{ml} \mathrm{h}^{-1}$ and fractions with $\alpha$-amylase inhibitory activity were pooled, precipitated at $90 \%$ ammonium sulphate saturation, dialysed and lyophilised. According to this purification procedure, $100 \mathrm{~g}$ seed floor yielded about $50 \mathrm{mg} \alpha$-AI isoform 1 and $20 \mathrm{mg} \alpha$-AI isoform 2.

\subsection{Enzyme assays}

The $\alpha$-amylase activity was measured by the method of Bernfeld [26]. To $0.4 \mathrm{ml}$ of $1 \%(\mathrm{w} / \mathrm{v})$ starch solution in $40 \mathrm{mM}$ phosphate buffer ( $\mathrm{pH}$ 6.9), $0.2 \mathrm{ml}$ of $\alpha$-amylase at $3.1 \times 10^{-7} \mathrm{M}$ in $4 \mathrm{mM}$ acetate buffer $(\mathrm{pH} 4.5)$ were added and the mixture was incubated at $30^{\circ} \mathrm{C}$ for $15 \mathrm{~min}$. Reaction was stopped by addition of $0.8 \mathrm{ml}$ of dinitrosalicylic acid reagent (DNS). $1 \mathrm{ml}$ of this solution was boiled for $10 \mathrm{~min}$, then cooled and diluted with $4 \mathrm{ml}$ of water and the absorbance was read at $540 \mathrm{~nm}$. Appropriate blanks were prepared without $\alpha$-amylase. Assays for $\alpha$-amylase inhibitor were performed as described above but $\alpha$-amylase and inhibitor were preincubated $1 \mathrm{~h}$ in $4 \mathrm{mM}$ acetate buffer $(\mathrm{pH} 4.5)$ before addition of the substrate.

\subsection{Analytical size-exclusion chromatography}

Experiments were performed at $4{ }^{\circ} \mathrm{C}$ on Superdex G75 10/30 (optimal separation range from 30 to 70 $\mathrm{kDa})$. The column was equilibrated with buffer $1(\mathrm{pH}$ 7.6). Samples $(100 \mu l)$ with protein concentrations of $2 \mathrm{mg} \mathrm{ml}{ }^{-1}$ were injected at a flow rate of $0.5 \mathrm{ml}$ $\min ^{-1}$ and fractions of $0.5 \mathrm{ml}$ corresponding to $\alpha$-AI were collected. The column was calibrated using bovine serum albumin $\left(67 \mathrm{kDa}, R_{\mathrm{s}}: 35.5 \AA\right.$ A), ovalbu$\min \left(43 \mathrm{kDa}, R_{\mathrm{s}}: 30.5 \AA\right)$ and chymotrypsinogen $\mathrm{A}$ (25 kDa, Rs: $20.9 \AA$ A) (Pharmacia). Elution volumes were measured for standard proteins and $\alpha$-AI. The
$K_{\text {av }}$ values were calculated for each protein using $K_{\mathrm{av}}=\left(V_{\mathrm{e}}-V_{0}\right) /\left(V_{t}-V_{0}\right)$. The Stokes radii $\left(R_{\mathrm{s}}\right)$ were calculated from the plot of $\left(-\log K_{\mathrm{av}}\right)^{1 / 2}$ vs. $R_{\mathrm{s}}$ and the molecular mass was calculated from the plot of $K_{\mathrm{av}}$ vs. log molecular mass.

\subsection{Haemagglutination assays}

The haemagglutinating activity of $\alpha$-AI was measured in U-bottomed micro-titration plates (Flow Laboratories). Briefly, $25 \mu \mathrm{l}$ of two-fold serial dilutions of $1 \mathrm{mg} \mathrm{ml}^{-1}$ of $\alpha$-AI in buffer $1(\mathrm{pH} \mathrm{7.4)}$ were mixed at room temperature with an equal volume of a $1 \%(\mathrm{v} / \mathrm{v})$ suspension of thrice-washed human $\mathrm{O}$ $\mathrm{Rh}+$ erythrocytes in the same buffer. Haemagglutination was read $2 \mathrm{~h}$ later at room temperature and, for control, after standing at $4^{\circ} \mathrm{C}$ for $12 \mathrm{~h}$.

\subsection{Surface plasmon resonance measurements}

The interaction of $\alpha$-AI with $\alpha$-amylases of different origins was monitored in real time by surface plasmon resonance (SPR) measurements using a biosensor BIAcore (Pharmacia Biosensor AB). $\alpha$ Amylases from human and porcine pancreas, B. subtilis and A. oryzae, used at a concentration of 100 $\mu \mathrm{g} \mathrm{ml}^{-1}$ in $4 \mathrm{mM}$ sodium acetate, $10 \mathrm{mM} \mathrm{CaCl}_{2}$ buffer ( $\mathrm{pH} 4.5$ ), were immobilised on the carboxymethyled dextran layer covering a CM 5 sensor chip (Pharmacia Biosensor) by the standard coupling procedure using $\mathrm{N}$-hydroxysuccinimide and $\mathrm{N}$-ethyl$N^{\prime}$-(3-dimethylaminopropyl) carbodiimide hydrochloride. According to the change of SPR response, expressed in resonance units (RU), as a result of the immobilization of $\alpha$-amylase on the carboxymethylated dextran layer, an estimated surface concentration of $10 \mathrm{ng} \mathrm{mm}{ }^{-2}$ of dextran was obtained for the immobilised proteins. $\alpha$-AI used at concentrations ranging from 100 to $500 \mu \mathrm{g} \mathrm{ml}^{-1}$ in $4 \mathrm{mM}$ sodium acetate, $10 \mathrm{mM} \mathrm{CaCl}{ }_{2}$ buffer ( $\left.\mathrm{pH} 4.5\right)$, was injected for 5 min onto the $\alpha$-amylase bound surface of the sensor chip at a flow rate of $5 \mu 1 \mathrm{~min}^{-1}$. The change of the SPR response (RU), was monitored at $25^{\circ} \mathrm{C}$ for $9.30 \mathrm{~min}$. The same $\alpha$-amylase sensor chip surface was used repeatedly after removing the remaining immobilised inhibitor by two successive 2 min washes with $10 \mathrm{mM} \mathrm{HCl}$ and $10 \mathrm{mM} \mathrm{NaOH}$, respectively. 


\subsection{Polyacrylamide gel electrophoresis}

Polyacrylamide gel electrophoresis (PAGE and SDS-PAGE) was carried out on the Phast System (Pharmacia) using ready-made $12.5 \%$ and $20 \%$ acrylamide gels. Isoelectrofocusing (IEF-PAGE) was performed in the $\mathrm{pH}$-range between $\mathrm{pH} 3.0$ and 9.0 on ready-made IEF 3-9 phastgels. The Coomassie blue staining method used to visualise the separated protein bands can detect 20-30 ng protein. For Western blotting, protein fractions were transferred electrophoretically onto a $0.45 \mu \mathrm{m}$ nitrocellulose membrane (Pharmacia) at $20 \mathrm{~V}$ for $30 \mathrm{~min}$. The membrane was first treated for $1 \mathrm{~h}$ with the blocking reagent [buffer $1(\mathrm{pH} 8.0)$ containing $0,5 \%(\mathrm{v} / \mathrm{v})$ Tween 20 (Sigma) and 5\% (w/v) gelatin (Bio-Rad)]. Then, it was incubated for $1.5 \mathrm{~h}$ at room temperature in $5 \mu \mathrm{g}$ $\mathrm{ml}^{-1}$ biotinylated Con A in buffer 1 ( $\left.\mathrm{pH} 8.0\right)$ containing $0,05 \%(\mathrm{v} / \mathrm{v})$ Tween $20,5 \%(\mathrm{w} / \mathrm{v})$ gelatin. After 3 washes in the same buffer devoid of lectin, the membrane was incubated in a 1:2000 dilution of streptavidin peroxidase in the same buffer for $1.5 \mathrm{~h}$. The labelled protein fractions were revealed by soaking the membrane for $15 \mathrm{~min}$ into a freshly prepared mixture containing $10 \mathrm{mg}$ 4-chloro-1-naphthol (Sigma), $3.3 \mathrm{ml}$ ice cooled methanol, $10 \mu \mathrm{H}_{2} \mathrm{O}_{2}$ $30 \%$ (Sigma) and $16.7 \mathrm{ml}$ buffer 1 (pH 7.6).

\subsection{Analytical methods}

The bicinchonic acid method [27] was carried out for protein determinations (Pierce), using bovine serum albumin (BSA) as standard. Total neutral sugar content of $\alpha$-AI was estimated colorimetrically by the phenol- $\mathrm{H}_{2} \mathrm{SO}_{4}$ method [28] using D-glucose as standard.

For sugar analyses, a sample $(200 \mathrm{mg})$ of $\alpha$-AI was routinely hydrolysed with $2 \mathrm{M}$ aqueous trifluoroacetic acid (Sigma) solution at $110^{\circ} \mathrm{C}$ for $1 \mathrm{~h}$. The hydrolysate was dried under nitrogen, then subject to trimethylsilylation as previously described by Sweeley et al. [29], and analysed by gas chromatography with a Girdel G-30 apparatus equipped with a fused silica column ( $25 \mathrm{~m}$ length by $0.22 \mathrm{~mm}$ internal diameter) coated with OV-1 (0.3 mm film thickness). A temperature gradient from 100 to $280^{\circ} \mathrm{C}\left(2^{\circ} \mathrm{C}\right.$ $\min ^{-1}$ ) was used.

\section{Results}

\subsection{Purification yield and purity}

According to our two-step purification procedure, $\alpha$-AI is eluted from the chromatofocusing column as a main peak around $\mathrm{pH} 4.6$ corresponding to $\alpha$-AI isoform $1(\alpha-\mathrm{AI} 1)$, followed by a shoulder around $\mathrm{pH}$ 4.3 corresponding to $\alpha$-AI isoform $2\left(\alpha-\mathrm{AI}^{\prime}\right)$ (Fig. 1). Ultimate purification procedure performed on a Sephadex G 200 column, gives a single symmetrical peak for both inhibitors (Fig. 2). The $\alpha$-AI yield is close to $50(0.05 \%, \mathrm{w} / \mathrm{w})$ and $20 \mathrm{mg}(0.02 \%, \mathrm{w} / \mathrm{w})$ of $\alpha$-AI1 and $\alpha$-AI1' for $100 \mathrm{~g}$ dry seeds. However, Marshall and Lauda [19] reported a yield of 0.4 to $0.5 \%$ for $\alpha$-AI from the white kidney bean ( $P$. vulgaris). The lower level of $\alpha$-AI found in $P$. vulgaris $\mathrm{cv}$. Tendergreen might be due to varietal differences but could also depends on the purification procedure. During our purification procedure, some $\alpha$-AI is probably discarded throughout the first ammonium sulphate precipitation $(40 \%)$. However, our $\alpha$-AI preparation was demonstrated to be devoid of any contamination by the closely related lectins (PHA-E and PHA-L) and lectin-like proteins (arcelins) which occur into the seeds, since the chromato-

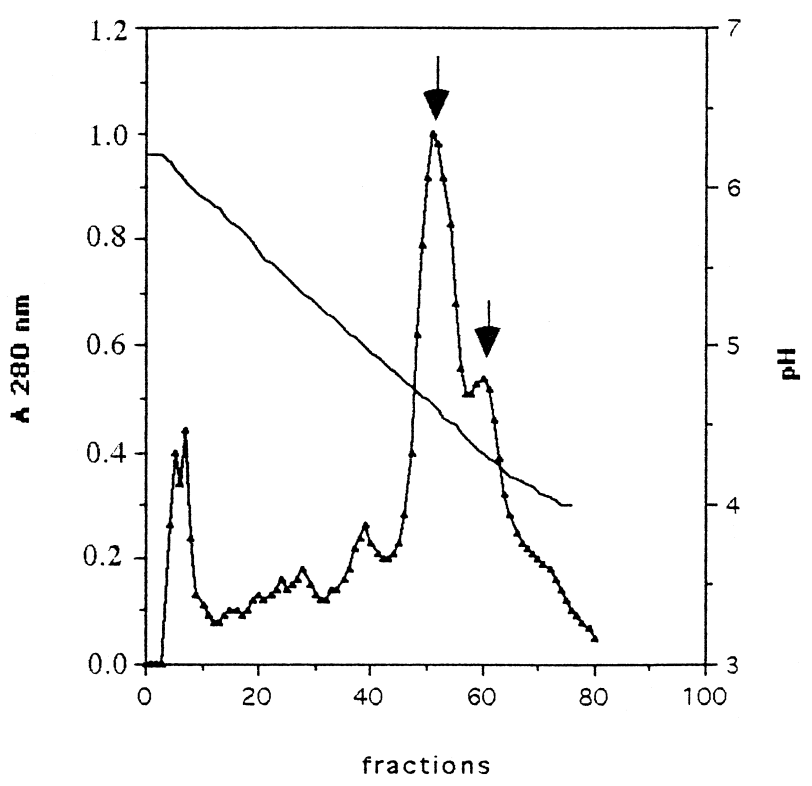

Fig. 1. Isolation of $\alpha$-AI isoform 1 and $\alpha$-AI isoform 2 by chromatofocusing on a PBE 94 column in the $\mathrm{pH}$-range between $\mathrm{pH} 6.2$ and 4.0. Arrows indicate the position of $\alpha$-AI isoform 1 and $\alpha$-AI isoform 2 . 


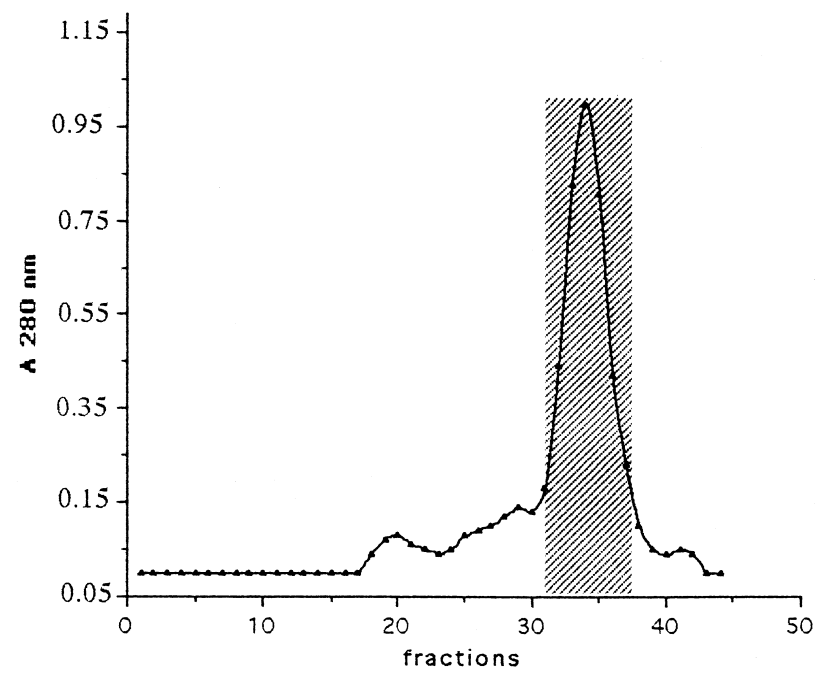

Fig. 2. Purification of $\alpha$-AI1 by gel filtration on a column of Sephadex G200 (100 $\mathrm{cm} \times 1.5 \mathrm{ml}$ bed volume). Elution was performed at a flow rate of $8.7 \mathrm{ml} \mathrm{h}^{-1}$. $\alpha$-AI1 was isolated as a symmetric peak (grey), eluted around $140 \mathrm{ml}$.

focusing step allow both PHA-E (pI 5.5), PHA-L ( $I$ 5.8) and arcelin ( $\mathrm{p} I$ 6.4) to be readily separated from $\alpha$-AI isoform $1(\mathrm{p} I$ 4.6) and $\alpha$-AI isoform 2 ( $\mathrm{p} I$ 4.3). When used at a concentration of $1 \mathrm{mg} \mathrm{ml}^{-1}$ in PBS ( $\mathrm{pH} 7.4)$, no agglutination of whether untreated or trypsin-treated human $\mathrm{O} \mathrm{Rh}+$ or rabbit red blood cells could be obtained. Under the same conditions, lectins and arcelin gave more or less pronounced haemagglutination titres when checked against untreated or trypsin-treated erythrocytes (Fabre et al. to be published). The absence of haemagglutonating activity of $\alpha$-AI probably depends on the lack of two of the four loops forming the monosaccharide-binding site of lectins $[4,8]$ which prevents this lectin-like protein to react with simple or complex sugars.

\subsection{Molecular structure of $\alpha-A I$}

By SDS-PAGE, the $\alpha$-AI preparation shows 3 polypeptide protein fractions in the $M_{\mathrm{r}}$ range between 14 and $19 \mathrm{kDa}$ together with another fraction of $32 \mathrm{kDa}$ (Fig. 3A). The polypeptide fractions of $M_{\mathrm{r}}$ 14-19 kDa correspond to $\alpha$ and $\beta$ subunits with different degrees of glycosylation [30]. However, it is often difficult to determine the molecular weight of a glycoprotein by SDS-PAGE because the glycopeptide-SDS complexes yield abnormally hight molecular weight estimates $[30,25]$. In this respect, the use of chemical and enzymatic deglycosylation method for $\alpha$ and $\beta$ subunits give $M_{\mathrm{r}}$ calculated from SDSPAGE experiments of 7.8 and $14 \mathrm{kDa}$, respectively [20]. The protein fraction of $M_{\mathrm{r}} 32 \mathrm{kDa}$ probably corresponds to the unprocessed $\alpha$-AI proprotein, as previously suggested by Moreno et al. [3] and Pueyo et al. [31]. All these protein fractions react with biotinylated ConA, thus indicating they are glycosylated. By IEF-PAGE, pI of 4.6 and 4.3 were measured for $\alpha-A I 1$ and $\alpha-A I 1^{\prime}$, respectively (Fig. 3B). Both $\alpha$-AI1 and $\alpha$-AI1 ${ }^{\prime}$ give a single protein band when analysed by PAGE in native conditions, with estimated $M_{\mathrm{r}}$ of 43.6 and $39.8 \mathrm{kDa}$, respectively (Fig. 3C). By chromatography sieving on a column of Sephadex G75 (Pharmacia), a $M_{\mathrm{r}}$ of $43 \mathrm{kDa}$ was calculated for $\alpha$-AI1 and $\alpha$-AI1'. Altogether, these results suggest that the differential migration observed in native PAGE is probably related to different isoelectric points of both $\alpha$-AI isoforms. These results also suggest that native $\alpha-\mathrm{AI}$ isoforms 1 and 2 both occur as homodimers $\left(\alpha_{2} \beta_{2}\right)$ with a Stokes radius of $29.0 \AA$, which corresponds to globular proteins. The neutral sugar contents of $\alpha-\mathrm{AI} 1$ and $\alpha$-AI1' determined according to the phenol- $\mathrm{H}_{2} \mathrm{SO}_{4}$ method of Dubois et al. [28], yielded respective values of $16 \%$ and $14 \%(\mathrm{w} / \mathrm{w})$. The oligosaccharide chains of both inhibitors are mainly composed of mannose associated to a trace of xylose, as estimated by vapour phase chromatography [32].

\subsection{Inhibition of porcine pancreatic $\alpha$-amylase by $\alpha-A I$}

\subsubsection{Effect of $p H$ on the inhibitory activity of $\alpha$-AI}

The extent to which $\alpha$-AI1 inhibits porcine pancreatic $\alpha$-amylase (PPA) was determined at different $\mathrm{pH}$ values using $4 \mathrm{mM}$ sodium acetate $(\mathrm{pH}$-range between 3.5 and 6.0) and $4 \mathrm{mM}$ potassium phosphate (pH-range between 6.5 and 7.5) buffers. The amylase activity remaining after a $1 \mathrm{~h}$ incubation at $30^{\circ} \mathrm{C}$ of PPA $\left(3.1 \times 10^{-7} \mathrm{M}\right)$ in the presence of $\alpha$-AI1 (11.6 $\left.\times 10^{-8} \mathrm{M}\right)$ was determined by adding $0.4 \mathrm{ml}$ of $1 \%$ starch solution (see Section 2). Controls were run at each $\mathrm{pH}$ value with PPA alone and the percentages of inhibition were calculated from the controls vs PPA: $\alpha$-AI values measured at each $\mathrm{pH}$. The extent of the inhibition of PPA by $\alpha$-AIl depends on the $\mathrm{pH}$ value with an optimum at approximately $\mathrm{pH} 4.5$ (Fig. 4). The inhibition drops markedly outside a narrow 

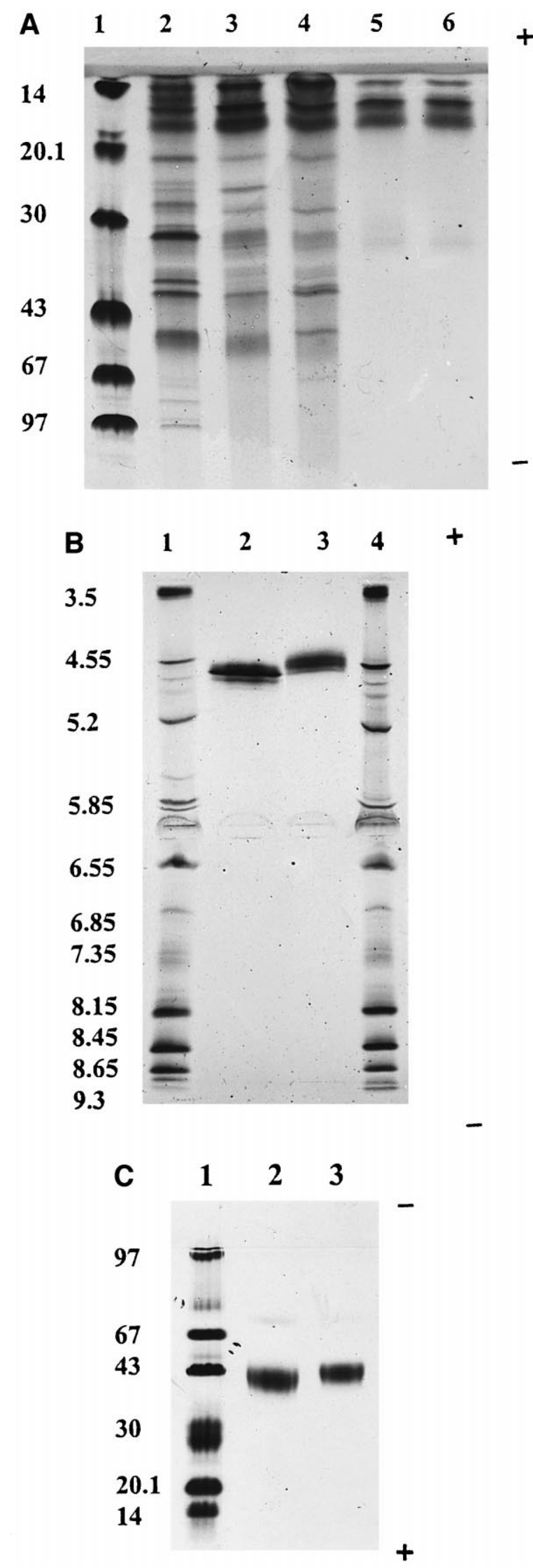

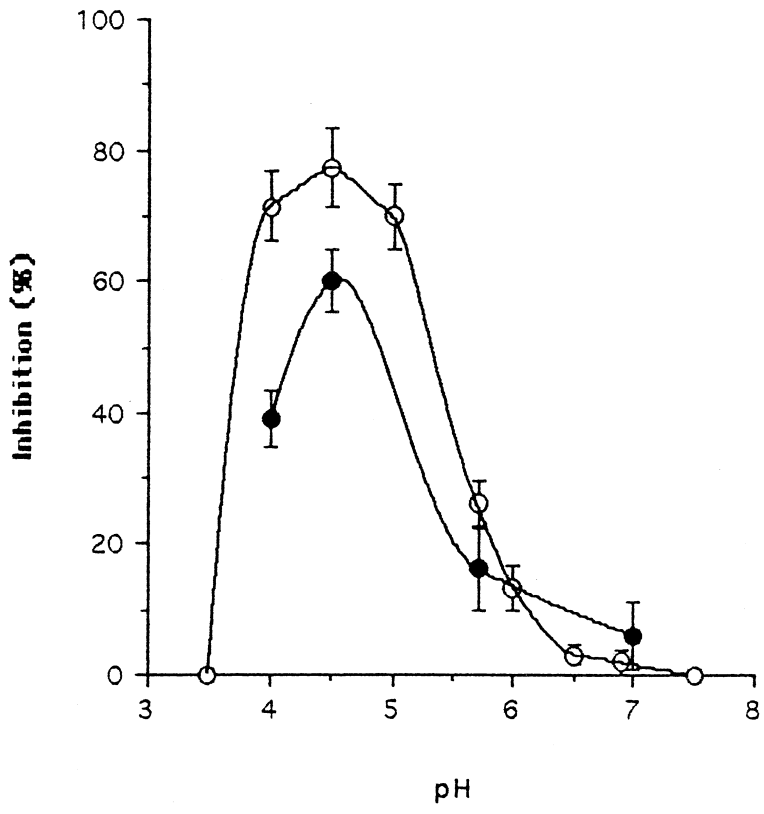

Fig. 4. $\mathrm{pH}$ dependence of the inhibitor activity of $\alpha$-AI1 towards porcine $(\bigcirc)$ and human $(O)$ pancreatic amylases. Porcine and human pancreatic amylases $\left(3.1 \times 10^{-7} \mathrm{M}\right)$ were incubated with $\alpha$-AI1 $\left(11.6 \times 10^{-8}\right.$ and $9.3 \times 10^{-8} \mathrm{M}$, respectively) at various pHs. Each value is the mean $\pm \mathrm{SD}$ of three separate experiments.

$\mathrm{pH}$-range around $\mathrm{pH}$ 4.5. Marshall and Lauda [19] found an optimum $\mathrm{pH}$ of 5.5 at $37^{\circ} \mathrm{C}$ for the inhibition of PPA by purified Great Northern white kidney bean $\alpha$-AI while Powers and Whitaker [22] reported

Fig. 3. (A) SDS-PAGE of purified $\alpha$-AI isoform 1 and $\alpha$-AI isoform 2 (lanes 5 and 6), compared to chromatofocusing inhibitor 1 and 2 containing fractions (lanes 3 and 4) and protein fraction precipitated at $40 \%$ ammonium sulphate saturation (lane 2). Molecular mass reference proteins (lane 1) are lysozyme (14 $\mathrm{kDa})$, soybean trypsin inhibitor $(20.1 \mathrm{kDa})$, carbonic anhydrase (30 kDa), ovalbumin (43 kDa), bovine serum albumin $(67 \mathrm{kDa})$ and phosphorylase b (94 kDa). $1 \mu \mathrm{l}$ of solution containing $2 \mathrm{mg}$ $\mathrm{ml}^{-1} \alpha$-AI was deposited onto the gel. (B) Isofocusing of purified $\alpha$-AI isoform 1 (lane 2) and $\alpha$-AI isoform 2 (lane 3). Isoelectric point reference proteins (lanes 1 and 4) are amyloglucosidase (3.50), soybean trypsin inhibitor (4.55), $\beta$-lactoglobulin A (5.20), bovine carbonic anhydrase (5.85), human carbonic anhydrase (6.55), horse myoglobin-acid (6.85), horse myoglobin-basic (7.35), lentil lectin-acidic (8.15), lentil lectin-middle (8.45), lentil lectin-basic (8.65) and trypsinogen (9.30). $1 \mu \mathrm{l}$ of a solution containing $2 \mathrm{mg} \mathrm{ml}^{-1} \alpha$-AI was deposited onto the gel. (C) Native PAGE of purified $\alpha$-AI isoform 1 and $\alpha$-AI isoform 2 (lane 3 and 2). Molecular mass reference proteins (lane 1) are lysozyme $(14 \mathrm{kDa})$, soybean trypsin inhibitor $(20.1 \mathrm{kDa})$, carbonic anhydrase $(30 \mathrm{kDa})$, ovalbumin $(43 \mathrm{kDa})$, bovine serum albumin $(67 \mathrm{kDa})$ and phosphorylase b $(94 \mathrm{kDa}) .1 \mu 1$ of solution containing $2 \mathrm{mg} \mathrm{ml}^{-1} \alpha$-AI was deposited onto the gel. 


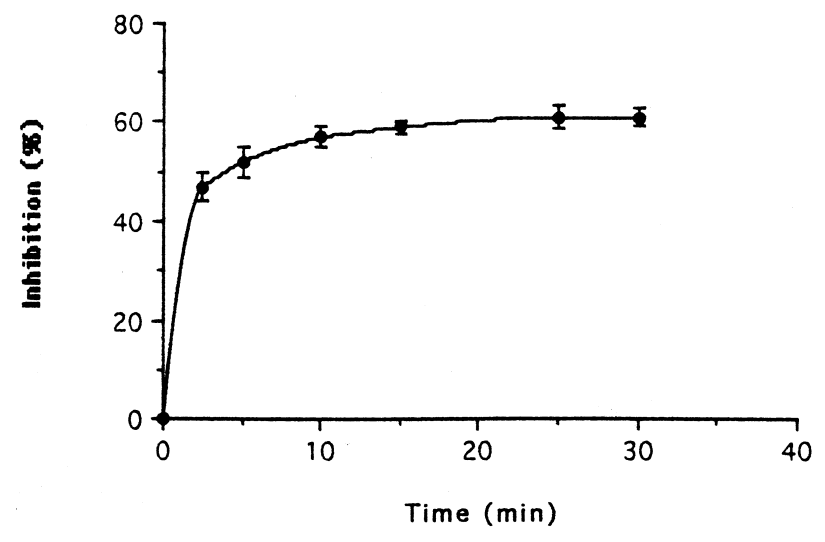

Fig. 5. Time course of inhibition of PPA by $\alpha$-AI 1 at $30^{\circ} \mathrm{C}$. $\alpha$-AI1 $\left(8.1 \times 10^{-8} \mathrm{M}\right)$ was preincubated with PPA $\left(3.1 \times 10^{-7}\right.$ $\mathrm{M})$, in $4 \mathrm{mM}$ sodium acetate $(\mathrm{pH} 4.5)$. Each value is the mean $\pm \mathrm{SD}$ of three separate experiments.

an optimum $\mathrm{pH}$ of 5.0 at $30^{\circ} \mathrm{C}$ for the inhibition of PPA by purified red kidney bean $\alpha$-AI. Similar experiments carried out with human pancreatic $\alpha$ amylase led to identical $\mathrm{pH}$ values with $\alpha$-AI1 (Fig. 4). These last results are in agreement with those reported by Lajolo and Finardi-Filho [24] which found an optimum $\mathrm{pH}$ of 4.5 for the inhibition of human salivary $\alpha$-amylase by $\alpha$-AI purified from black kidney bean var. Rico 23 .

\subsubsection{Time and temperature dependence of the $\alpha$ - amylase inhibition}

PPA $\left(3.1 \times 10^{-7} \mathrm{M}\right)$ and $\alpha$-AI1 $\left(8.1 \times 10^{-8} \mathrm{M}\right)$ were incubated in $4 \mathrm{mM}$ acetate buffer $(\mathrm{pH} 4.5)$ at $30^{\circ} \mathrm{C}$. At different times, $1 \%$ reduced starch was added in order to determine the amount of amylase activity. The data showed that the interaction between $\alpha$-amylase and $\alpha$-AI 1 is fast since the maximum inhibition was achieved after $10 \mathrm{~min}$ of incubation (Fig. 5). Very different results were reported for $\alpha$-AIs from Great Northern bean [19] and red kidney bean [22] which reached the maximum inhibition after 40 and $120 \mathrm{~min}$, respectively.

The effect of three different temperatures $(22,30$ and $37^{\circ} \mathrm{C}$ ) on the inhibition of PPA by $\alpha$-AI1 was recorded at the optimum $\mathrm{pH}$ of 4.5 . The similar inhibition percentages obtained at $22(61 \%), 30(54 \%)$ and $37^{\circ} \mathrm{C}(64 \%)$ clearly show that temperature exhibits a moderate effect on the activity of $\alpha$-AI1. Marshall and Lauda [19] reported a 10-fold increase in activity of the $\alpha$-amylase inhibitor when the tem- perature of the reaction was raised from 25 to $37^{\circ} \mathrm{C}$. Such a discrepancy might be related to the different $\mathrm{pH}$ values used in both experiments since their enzymatic measurements were performed at $\mathrm{pH} 6.9$ which is the optimum $\mathrm{pH}$ for the porcine pancreatic $\alpha$ amylase activity and not the optimum $\mathrm{pH}$ for the $\alpha$-amylase inhibition.

\subsubsection{Specificity of the $\alpha$-amylase-inhibitor interac- tion}

The specificity of $\alpha$-AI1 towards $\alpha$-amylases of various origins was checked after a preincubation at $30^{\circ} \mathrm{C}$ of the enzyme $\left(3.1 \times 10^{-7} \mathrm{M}\right)$ with the inhibitor $\left(4.7 \times 10^{-7} \mathrm{M}\right)$. Whatever the $\mathrm{pH}$ used $(\mathrm{pH}$ $4.5,5.8$ or 7.0 ) for the preincubation step, no inhibition occurred with $\alpha$-amylases of bacterial ( $B$. subtilis) or fungal ( $A$. oryzae) origins while $\alpha$-amylases from porcine and human pancreas were inhibited at $95 \%$ and $90 \%$ at $\mathrm{pH} 4.5$, respectively. These result agree with those reported by Marshall and Lauda [19], but disagree from those of Jaffé et al. [33] who reported that a partially purified inhibitor from kidney bean, inhibited porcine pancreatic $\alpha$-amylase, human salivary $\alpha$-amylase and, to a lesser extent, $\alpha$-amylase from $B$. subtilis. This result was confirmed by monitoring in real time by surface plasmon resonance (SPR) measurements, the interaction of $\alpha$-AI1 (100 $\left.\mu \mathrm{g} \mathrm{ml}^{-1}\right)$ with these previously immobilised $\alpha$-amylases of different origins (Fig. 6). Only human and porcine pancreatic $\alpha$-amylase interacted with purified $\alpha$-amylase inhibitors.

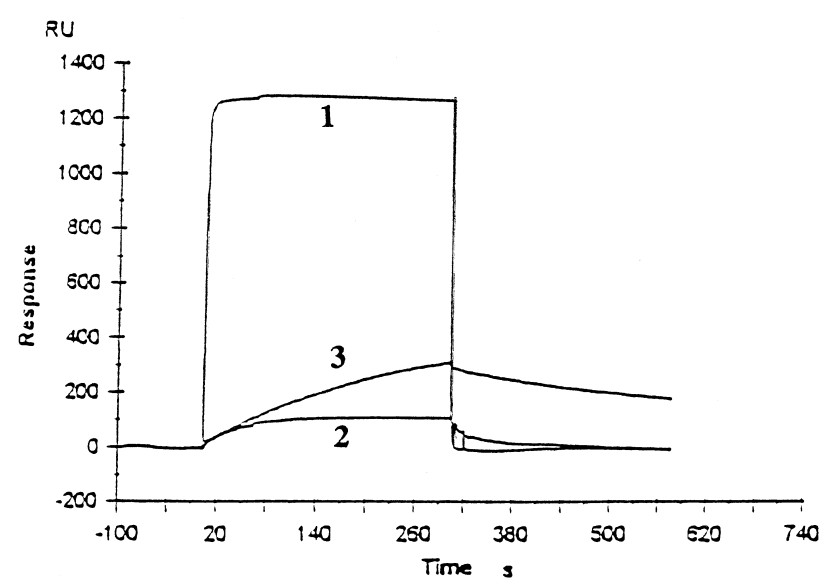

Fig. 6. Interaction of $\alpha$-AI1 with $\alpha$-amylases of different origins, monitored in real time by surface plasmon resonance (SPR). (1) $\alpha$-amylase from $A$. oryzae, (2) $\alpha$-amylase from B. subtilis, (3) $\alpha$-amylase from porcine pancreas. 


\subsubsection{Stoichiometry of the complex $\alpha$-amylase-in- hibitor}

Stoichiometry of the reaction between $\alpha$-AI1 and porcine pancreatic $\alpha$-amylase was determined by incubating a fixed amount of enzyme $\left(3.1 \times 10^{-7} \mathrm{M}\right)$ with varying amounts of inhibitor (ranging from 5.7 $\times 10^{-8}$ to $\left.2.3 \times 10^{-7} \mathrm{M}\right)$ at $\mathrm{pH} 4.5$ (Fig. 7). The inhibition of $3.1 \times 10^{-7} \mathrm{M}$ porcine pancreatic $\alpha$ amylase by $8.1 \times 10^{-8} \mathrm{M} \alpha$-AI1 approaches $50 \%$, the theoretical percentage of inhibition calculated for an enzyme:inhibitor ratio of $2: 1$. This result contrasts with all the previous results reported until now which mention a 1:1 stoichiometry for the PPA: $\alpha$-AI complex [19,22,34]. Recently, Kasahara et al. [7] have detected a significant amount of 2:1 PPA: $\alpha$-AI complex together with a 1:1 PPA: $\alpha$-AI complex by submitting a mixture of equimolar amounts of PPA and $\alpha$-AI purified from white kidney bean to gel chromatography. The 2:1 stoichiometry measured for the PPA: $\alpha$-AI1 complex is in complete agreement with the X-ray analysis of a PPA: $\alpha$-AI1 (from P. vulgaris tendergreen) complex showing two molecules of PPA interacting with a single $\alpha$-AI1 dimer [8].

\subsubsection{Nature of $\alpha$-amylase inhibition by $\alpha$-amylase- inhibitor}

To ascertain whether inhibition of PPA by $\alpha$-AI1 was competitive or non-competitive, LineweaverBurk plots were drawn for the non-inhibited and partly inhibited enzyme. The rate of $\alpha$-amylase activity was determined at different substrate concentrations $(0.2,0.3,0.4$ and $0.5 \%$ starch, respectively)

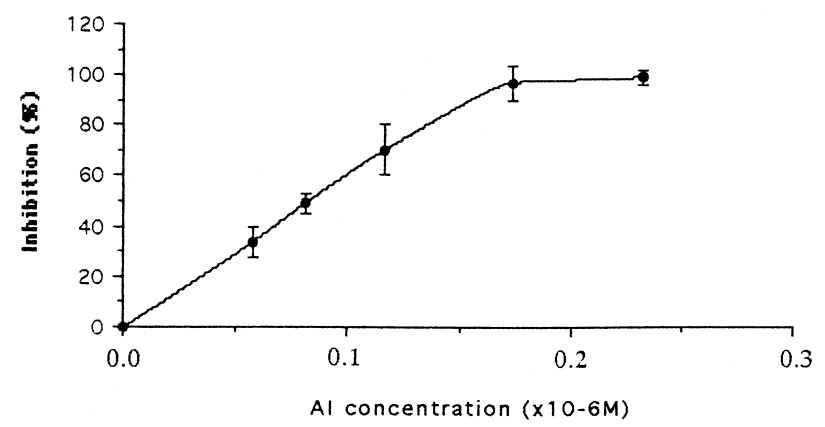

Fig. 7. Determination of the stoichiometry of PPA: $\alpha$-AI1 interaction. PPA $\left(3.1 \times 10^{-7} \mathrm{M}\right)$ was incubated $30 \mathrm{~min}$ at $30^{\circ} \mathrm{C}$ with various amounts of inhibitor $\left(5.7 \times 10^{-8}\right.$ to $\left.2.3 \times 10^{-7} \mathrm{M}\right)$, in 4 $\mathrm{mM}$ sodium acetate buffer $\mathrm{pH}$ 4.5. Each value is the mean $\pm \mathrm{SD}$ of six separate experiments.

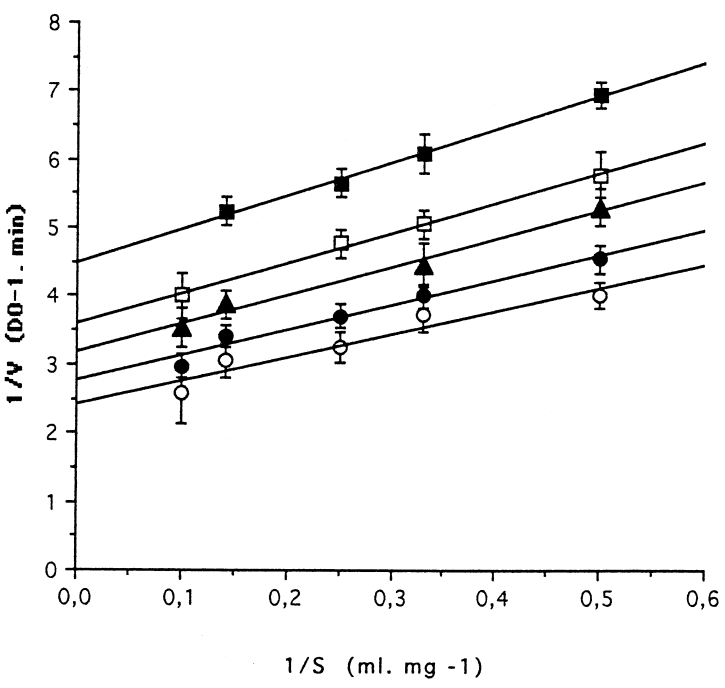

Fig. 8. Lineweaver-Burk plots of activity of PPA alone $(\bigcirc)$ and partly inhibited PPA with $\alpha$-AI1 at $4.65 \times 10^{-8}(\bigcirc), 8.14 \times 10^{-8}$ $(\boldsymbol{\Delta}), 1.16 \times 10^{-7}(\square)$ and $1.5 \times 10^{-7} \mathrm{M}(\boldsymbol{\square})$. The assay digests $(0.8 \mathrm{ml})$ contained different concentration of soluble starch in 40 $\mathrm{mM}$ phosphate buffer $(\mathrm{pH} 6.9)$ and enzyme $\left(6.4 \times 10^{-7} \mathrm{M}\right)$ alone or previously incubated in the presence of $\alpha$-AI1 $\left(1.16 \times 10^{-7}\right.$ M). The slopes were calculated by linear regression using the mean \pm SD of three separate experiments.

with the enzyme alone preincubated in $4 \mathrm{mM}$ acetate buffer $(\mathrm{pH} 4.5)$ at $30^{\circ} \mathrm{C}\left(6.4 \times 10^{-7} \mathrm{M}\right)$ and after preincubation with different inhibitor concentrations $\left(4.65 \times 10^{-8}\right.$ to $\left.1.5 \times 10^{-7} \mathrm{M}\right)$. The LineweaverBurk plots for the uninhibited and partly inhibited enzyme exhibited different slopes and intersected at different locations in the third quadrant (Fig. 8). The fact that intercepts occur in the third quadrant in the Lineweaver-Burk plots is better explained by the recently proposed mixed non-competitive inhibition mechanism for the PPA-acarbose complex [35]. This treatment assumes that enzyme-inhibitor interaction is not irreversible. These results are not in full agreement with those of Marshall and Lauda [19] who previously reported a non-competitive inhibition for $\alpha$-AI from red kidney bean ( $P$. vulgaris var. Great Northern).

\section{Discussion}

Preliminary purification trials indicating an unusual stability of the inhibitor when exposed to low 
$\mathrm{pH}$ even at elevated temperature, this property was exploited in the design of a highly selective extraction procedure. Instead of ion-exchange chromatography $[20,21,24,34,36]$ or affinity batch adsorption with immobilised $\alpha$-amylase on a CNBr-activated Sepharose 4B [19,30] commonly used for kidney bean $\alpha$-amylase inhibitor isolation, a chromatofocusing step was performed to purify this protein. This purification procedure allowed the separation of two $\alpha$-AI isoforms and this is, to our knowledge, the first report for the occurrence of two distinct $\alpha$-AI forms in the kidney bean seeds. None of these isoforms could correspond to $\alpha$-AI2 [37,38] since it only occurs in wild beans and has never been found in cultivated common bean. Moreover, Ishimoto et al. [38] have demonstrated that $\alpha$-AI2 is devoid of any inhibitory activity towards porcine pancreatic $\alpha$ amylase. None of these isoforms could neither correspond to $\alpha-\mathrm{AI} 3$ since its banding pattern on SDSPAGE consists of one major polypeptide band associated to three minor bands [38]. In addition, its $M_{\mathrm{r}}$ should be higher than that observed for both $\alpha$-AI isoforms since its cDNA-deduced amino-acid sequence [39] exhibits an additional 20 residues. The two $\alpha$-AI isoforms isolated in this work exhibited the same $M_{\mathrm{r}}$ of $43 \mathrm{kDa}$ as measured by chromatography on Superdex 75, but differ from each other by their $\mathrm{p} I$ and the extent of $\mathrm{N}$-glycosylation. Both $\mathrm{N}$ - and $\mathrm{C}$-terminal sequencing and glycan chain analysis are underway to elucidate the exact relationship occurring between these two isoforms.

Inhibition of PPA with increasing amounts of $\alpha$ AI1 indicated that an inactive 2:1 complex is formed between PPA and $\alpha$-AI1. This stoichiometry is confirmed by the X-ray analysis at $1.85 \AA$ resolution of the PPA: $\alpha$-AI1 complex [8] which clearly revealed a dimeric structure for the inhibitor in complex with two molecules of PPA. Similarly, a 2:1 stoichiometry was found by Kasahara et al. [7] for the PPA: $\alpha-A I$ complex when a molecular ratio of $1: 1$ or $2: 1$ was used for both reactants. These data disagree with the 1:1 stoichiometry previously reported for the PPA: $\alpha$ AI complex by Marshall and Lauda [19], Powers and Whitaker [22] and Pick and Wöber [34]. Obviously, this $2: 1$ stoichiometry enhances the inhibitory power of $\alpha$-AI towards $\alpha$-amylase.

Studies on the optimum conditions for inhibition of PPA were focused on $\alpha$-AI1 and showed that inhibition of amylase is time- and $\mathrm{pH}$-dependant, but not significantly depends on the temperature between 22 and $37^{\circ} \mathrm{C}$.

The optimum $\mathrm{pH}$ is 4.5 for the inhibition of porcine and human pancreatic $\alpha$-amylases by $\alpha$-AI1. This low optimum $\mathrm{pH}$ value could explain why $\alpha$-AI is highly active on the midgut $\alpha$-amylase of insects and, especially, $\alpha$-amylase from Coleoptera which have an acidic $\mathrm{pH}$ in their midgut $[16,40]$. Seeds of common beans are resistant to bruchid larvae ( Callosobruchus maculatus and Callosobruchus chinensis) largely because of the presence of $\alpha$-AI [13-15]. In this respect, the postharvest damage caused by larvae of bruchids which is responsible for considerable crop losses could be prevented by introducing the gene encoding the kidney bean $\alpha$-AI into other transgenic plants [16-18]. Although this strategy could allow a better protection of cultivated plants against seed-eating larvae of Coleoptera, the occurrence of exogenous $\alpha$-AI in edible seeds is questionable with respect to human health since a perfusion of $\alpha$-AI into the duodenum was shown to inhibit human $\alpha$-amylase [11]. However, owing to the low optimum $\mathrm{pH}$ found for $\alpha$-AI1 activity, this finding is rather surprising because this intraduodenal inhibition occurs at a $\mathrm{pH}$ value around 6-7 which results from the mixing of the basic pancreatic juice with the acidic stomachal content. According to the data of Fig. 4, this inhibition is probably due to the residual activity developed at neutral $\mathrm{pH}$ by $\alpha$-AI when administered at so very high doses $\left(5 \mathrm{mg} \mathrm{ml}^{-1}\right)$. Along this line, the much more lower amounts of $\alpha$-AI $(\max 0.5 \%, \mathrm{w} / \mathrm{w})$ occurring in inhibitor-containing diets derived from transgenic plants should be devoid of any harmful effect on human health.

The influence of temperature on the larvae development was investigated by Menusan [41]. It appeared that the optimum development occurs at $24^{\circ} \mathrm{C}$ and $80 \%$ hygrometry, respectively. Therefore, it is of particular interest that inhibition of $\alpha$-amylase by $\alpha$-AI1 shows no significant difference between 22 and $37^{\circ} \mathrm{C}$, that means that $\alpha$-AI is fully reactive at temperatures allowing the best larval growth and development into the seeds.

The inhibition of PPA by $\alpha$-AI1 could be interpreted on the basis of a mixed non-competitive mechanism of the abortive type as previously reported for the PPA:acarbose complex [35]. Accordingly, the 
interaction of $\alpha$-AI1 with the active binding site of PPA has been clearly demonstrated by X-ray studies on the PPA: $\alpha$-AI1 complex obtained by co-crystallization of both molecules [8]. However, additional experiments using various substrates of different molecular sizes are in progress to discriminate among the few models involving abortive complexes.

\section{Acknowledgements}

This work was supported by CNRS and the Conseil Régional de Midi-Pyrénées (VL-A, PR). The skilful assistance of A.M. Mazard is gratefully acknowledged. We thank Prof. G. Marchis-Mouren for helpful discussion on the enzymatic mechanisms.

\section{References}

[1] R. Sanchez-Monge, L. Gomez, F. Garcia-olmedo, G. Salcedo, FEBS J. 207 (1986) 105-109.

[2] J.R. Whitaker, In: J.E. Kinsella, W.G. Soucle (Eds.), Food proteins, Proc. Prot. Co-prod. Symp., Am. Oil Chem. Soc., Champaign, IL, 1988, pp. 354-380.

[3] J. Moreno, M.J. Chrispeels, Proc. Natl. Acad. Sci. USA 86 (1989) 7885-7889.

[4] P. Rougé, A. Barre, H. Causse, C. Chatelain, G. Porthé, Biochem. Syst. Ecol. 21 (1993) 695-703.

[5] T.E. Mirkov, S.V. Evans, J. Wahlstrom, L. Gomez, N.M. Young, M.J. Chrispeels, Glycobiology 5 (1995) 45-50.

[6] P. Rousseau, A. Barre, H. Causse, C. Chatelain, G. Porthé, P. Rougé, In: A. Pusztai, S. Bardocz (Eds.), Lectins: Biomedical Perspectives, Taylor and Francis, London, 1995, pp. 23-33.

[7] K. Kasahara, K. Hayaski, T. Arakawa, J.S. Philo, J. Wen, S. Hara, H. Yamaguchi, J. Biochem. 120 (1996) 177-183.

[8] C. Bompard-Gilles, P. Rousseau, P. Rougé, F. Payan, Structure 4 (1996) 1441-1452.

[9] I.H. Rosenberg, New Engl. J. Med. 307 (1982) 1444-1445.

[10] I.E. Liener, D.A. Donatucci, J.C. Tarcza, Am. J. Clin. Nutr. 39 (1984) 196-200.

[11] P. Layer, G.L. Carlson, E.P. Dimagno, Gastroenterology 88 (1985) 1895-1902.

[12] P. Layer, R.A. Rizza, A.R. Zinsmeister, G.L. Carlson, E.P. Dimagno, Mayo Clin. Proc. 61 (1986) 442-447.

[13] M. Ishimoto, K. Kitamura, Appl. Ent. Zool. 24 (1989) 281-286.

[14] J.E. Huesing, R.E. Shade, M.J. Chrispeels, L.L. Murdock, Plant Physiol. 96 (1991) 993-996.
[15] M. Ishimoto, M.J. Chrispeels, Plant Physiol. 111 (1996) 393-401.

[16] T. Altabella, M.J. Chrispeels, Plant Physiol. 93 (1990) 805-810.

[17] R.E. Shade, H.E. Schroeder, J. Pueyo, L.M. Tabe, L.L. Murdock, T.J.V. Higgins, M.J. Chrispeels, Bio/Technology 12 (1994) 793-796.

[18] H.E. Schroeder, S. Gollasch, A. Moore, L.M. Tabe, S. Craig, D.C. Hardie, M.J. Chrispeels, D. Spencer, T.J.V. Higgins, Plant Physiol. 107 (1995) 1233-1239.

[19] J.J. Marshal, C.M. Lauda, J. Biol. Chem. 250 (1975) 80308037.

[20] H. Yamaguchi, J. Biochem. 110 (1991) 785-789.

[21] J.R. Powers, J.R. Whitaker, J. Food Biochem. 110 (1977) 217-238

[22] J.R. Powers, J.R. Whitaker, J. Food Biochem. 110 (1977) 239-260.

[23] E.R. Wilcox, J.R. Whitaker, J. Food Biochem. 8 (1984) 189-213.

[24] F.M. Lajolo, F. Finardo Filho, J. Agric. Food Chem. 33 (1985) 132-138.

[25] H. Yamaguchi, Biosci. Biotech. Biochem. 57 (1993) 142144.

[26] P. Bernfeld, Methods Enzymol. 1 (1955) 149-158.

[27] P.K. Smith, R.I. Krohn, G.I. Hermanson, A.K. Mallia, F.H. Gartner, M.D. Provenzano, E.K. Fujimoto, N.M. Groeke, B.J. Olson, D.C. Klenk, Ann. Biochem. 150 (1985) 76-85.

[28] M. Dubois, K.A. Gilles, J.K. Hamilton, P.A. Rebers, F. Smith, Anal. Chem. 28 (1956) 350-356.

[29] C.C. Sweeley, R. Bentley, M. Makita, W.W. Wells, J. Am. Chem. Soc. 85 (1963) 2497-2507.

[30] J. Moreno, T. Altabella, M.J. Chrispeels, Plant Physiol. 92 (1990) 703-709.

[31] J.J. Pueyo, D.C. Hunt, M.J. Chrispeels, Plant Physiol. 101 (1993) 1341-1348.

[32] H. Yamaguchi, H. Funaoka, H. Iwamoto, J. Biochem. 111 (1992) 388-395.

[33] W.G. Jaffé, R. Moreno, V. Wallis, Nutr. Rep. Irit. 7 (1973) 169-174.

[34] K.H. Pick, G. Wöber, Hoppe-Seyler's Z. Physiol. Chem. 359 (1978) 1371-1377.

[35] M. Alkazaz, V. Desseaux, G. Marchis-Mouren, F. Payan, E. Forest, M. Santimone, Eur. J. Biochem. 241 (1996) 787-796.

[36] M. Kotaru, K. Saito, H. Yoshikawa, T. Ikeuchi, F. Ibuki, Agri. Biol. Chem. 51 (1987) 577-578.

[37] K. Suzuki, M. Ishimoto, K. Kitamura, Biochem. Biophys. Acta 1206 (1994) 289-291.

[38] M. Ishimoto, K. Suzuki, M. Iwanaga, F. Kikuchi, Theor. Appl. Genet. 90 (1995) 425-429.

[39] T.E. Mirkov, J.M. Wahlstrom, K. Hagiwara, F. FinardiFilho, S. Kjemtrup, M.J. Chrispeels, Plant Mol. Biol. 26 (1994) 1103-1113.

[40] J.A.T. Dow, Adv. Insect Physiol. 19 (1986) 187-328.

[41] H. Menusan, Ann. Ent. Soc. Am. 29 (1936) 279-288. 